УДК 347.1

DOI https://doi.org/10.32849/2663-5313/2021.4.09

\title{
Роман Пожоджук,
}

канд. юрид. наук, старший дослідник,

старший науковий співробітник лабораторії адаптаиї законодавства Украӥни

до права Свропейського Союзу

Науково-дослідного інституту приватного права і підприємництва

імені академіка Ф.Г. Бурчака

Національної академї правових наук Украӥни

\section{МІСЦЕ СПОЖИВЧИХ ВІДНОСИН У СИСТЕМІ ЦИВІЛЬНОГО ПРАВА}

Статтю присвячено аналізу споживчих відносин та встановленню їх місия в системі иивільного права. Зокрема, автором досліджено сутність приватноправових відносин за участю фізичних осіб-споживачів шляхом аналізу положень чинного законодавства Украӥни та наукових позииї щодо наведених відносин. До того ж зазначено, що встановлення місия споживчих відносин у системі права Украйни є особливо актуальним в умовах виконання положень Угоди про асоціачію між Україною, з однієї сторони, та Свропейським Союзом, Свропейським співтовариством з атомної енергії і їніми державами-членами, з іншої сторони, задля приведення законодавства України до асqиіs coттипаитаire. Водночас для належного виконання відповідних зобов'язань України необхідно підготувати належну теоретико-правову базу.

Крім того, у статті наведено теоретичні міркування щодо відмінностей спожсвчих та цивільних відносин, доведено, що споживчі відносини охоплюють як майнові, так і особисті немайнові відносини, а також зазначено, що споживчі відносини регулюються нормами цивільного права. Автором обгрунтовано спорідненість споживчих відносин (приватноправових відносин за участю фізичних осіб-споживачів) та цивільно-правових. Також у межах дослідження висловлено міркування щодо необхідності розділення публічно-правових та приватноправових відносин за участю фізичних осіб-споживачів, останні з яких називаються споживчими відносинами і які належать до предмета иивільного права. Інакше може бути порушена спорідненість споживчих та цивільних відносин.

Як наслідок, автор робить спробу визначити місче споживчих відносин у системі цивільного права та доходить висновку, що споживчі відносини слід розглядати як иивільно-правові відносини за участю фізичних осіб-споживачів. Як особливий вид иивільно-правових відносин споживчі відносини мають специфічний суб'єктний склад, особливість поєднання диспозитивного та імперативного правового регулювання, спеціальний об'єкт - блага, що задовольняють особисті потреби фізичних осіб.

Також запропоновано авторську схему, якою зображується місие споживчих відносин у системі ицвільного права.

Ключові слова: відносини за участю споживачів, цивільно-правові відносини, захист прав споживачів, приватноправові відносини, публічно-правові відносини, споживач.

Постановка проблеми. Українське законодавство про захист прав споживачів налічує лише кілька десятків років та все ще перебуває на стадії формування. Сьогодні на державному рівні здійснюються відповідні заходи щодо вдосконалення системи захисту прав споживачів в України. Так, відповідно до статті 415 Глави 20 «Захист прав споживачів» Угоди про асоціацію між Україною, з однієї сторони, та Європейським Союзом, Європейським співтовариством 3 атомної енергії і їхніми державами-членами, з іншої сторони, Україна зобов'язалася забезпечити високий рівень захисту прав споживачів та досягнути сумісності між системами захисту прав споживачів України та державчленів Свропейського Союзу.
Задля реалізації зазначених положень Урядом України було схвалено Концепцію державної політики у сфері захисту прав споживачів на період до 2020 року, у якій, зокрема, зазначено, що система захисту прав споживачів у європейських країнах посідає одне з провідних місць у процесі формування економічної та соціальної політики. Це означає, що для вдосконалення вітчизняної системи захисту прав споживачів слід керуватися, зокрема, основними засадами захисту прав споживачів, що діють у країнах-членах Європейського Союзу. Водночас для належного виконання відповідних зобов'язань України необхідно підготувати грунтовну теоретико-правову базу та визначити місце споживчих відносин у вітчизняній правовій системі. 
Метою статті є проведення аналізу положень законодавства та доктрини для встановлення місця споживчих відносин у системі цивільного права для подальшого їх впорядкування та здійснення належних теоретико-правових досліджень.

Виклад основного матеріалу. Цивільноправові відносини між суб'єктом господарювання і фізичною особою, яка придбаває, замовляє, використовує або має намір придбати чи замовити продукцію для особистих потреб, безпосередньо не пов'язаних з підприємницькою діяльністю або виконанням обов'язків найманого працівника, виникають, змінюються і припиняються на підставі норм цивільного права та цивільно-правового договору, тобто можна стверджувати, що ці правовідносини, які ми називаємо споживчими відносинами, фактично є цивільноправовими і посідають почесне особливе місце у предметі цивільного права.

Проте така позиція не $є$ аксіомною, а в науці висловлювались інші думки щодо кваліфікації місця споживчих відносин. Так, на переконання О.О. Райляна, споживче правовідношення - це самостійний вид суспільних відносин. 3 цивілістичної точки зору, це специфічна форма соціальної приватноправової взаємодії суб'єктів споживчого права у сфері споживчого ринку задля реалізації інтересів і досягнення результатів, передбачених укладеними договорами, споживчим законодавством та прийнятими відповідно до нього іншими нормативно-правовими актами, а також техніко-юридичними нормами. Остання обставина дає підставу стверджувати, що приватноправові споживчі відносини - це особливий вид цивільних відносин, ускладнених істотним публічним елементом [1, с. 14-15]. Таким чином, автор пропонує розглядати споживче правовідношення під різними кутами зору, але як самостійний вид суспільних відносин.

Однак досить важко погодитися з міркуванням про те, що споживчі відносини є самостійним видом суспільних відносин. Насамперед слід звернути увагу на той факт, що підставою виникнення споживчих відносин є саме переддоговірні чи договірні відносини, що повністю охоплюються предметом цивільного права. Ця залежність дає можливість дійти закономірного висновку, що споживчі відносини були б об'єктивно неможливими без існування цивільного інституту зобов'язального права, тому така взаємопов'язаність споживчих відносин не дає нам змогу зробити висновок про їх самостійність та незалежність від цивільних.
Більш того, як влучно зазначив І.Б. Новицький, зобов'язання є різновидом цивільних правовідносин. Зміст будь-якого цивільного правовідношення включає право (в цьому разі право вимоги) і відповідний йому обов'язок або права та обов'язки на стороні кожного учасника правовідносин (наприклад, права та обов'язки постачальника й покупця, підрядника і замовника) [2, с. 35], тобто зміст споживчих відносин як цивільних включає право вимоги й відповідний йому обов'язок, а розглядаючи споживчі відносини як окремий вид суспільних відносин, фактично констатуємо вихід за межі предмета цивільного права чи надаємо першочергове значення саме зобов'язальному. Отже, споживчі відносини як такі, що виникають на підставі договору, є певним зобов'язанням сторін, що однозначно слід розглядати виключно під кутом зору цивільного права. Інакше може створитися небезпечний прецедент щодо штучного виведення істинно приватноправових норм із предмета правового регулювання цивільного права. При цьому прогнозована ефективність такого виведення порівняно 3 наявною практикою цивільно правового регулювання відносин за участю споживачів є досить сумнівною.

Погоджуючись із позицією О.О. Райляна стосовно можливості кваліфікації приватноправових споживчих відносин як особливого виду цивільних правовідносин, вважаємо все ж таки ці відносини a priori приватноправовими. На наше переконання, необхідність виокремлення та надання самостійного значення споживчим відносинам як цивільно-правовим обумовлена насамперед необхідністю врегулювання нових суспільних відносин, що виникають між споживачем та суб'єктом господарювання, оскільки сьогодні стрімкий розвиток відносин споживання значно випереджає їх законодавче регулювання. При цьому таке виокремлення споживчих відносин дасть змогу надати значному масиву правовідносин спеціального правового регулювання без порушення предметного регулювання цивільного права і навіть з урахуванням того, що ці відносини містять певний публічний елемент.

Окремо в контексті публічного елементу у споживчих відносинах слід навести міркування I.I. Банасевич, яка зазначає, що істотною особливістю цивільних правовідносин за участю споживача є їх комплексний (приватно-публічний) характер, зумовлений нерівним становищем споживача як слабкої сторони договірних відносин. Публічний характер правовідносин за участю споживача визначається тим, що держава, здійснюючи 
регулювання економіки загалом, розглядає захист прав споживачів не просто як один із інститутів права, а як один із пріоритетних напрямів своєї діяльності, спрямований на забезпечення конституційних прав людини й громадянина на життя, здоров'я, безпечне навколишнє середовище тощо [3]. Погоджуючись із позицією автора щодо істотної особливості споживчих відносин внаслідок наявності певного публічного елементу, вважаємо недоцільним кваліфікувати їх як комплексні. Це обумовлюється тим фактом, що цивільно-правові відносини навіть за наявності публічного елементу не втрачають своєї істинної сутності, більш того, можуть продовжувати існування навіть за його втрати (що не виключено з урахуванням еволюції цивільно-правових відносин).

Крім того, не зовсім погоджуємося з міркуванням автора стосовно того, що публічний характер правовідносин за участю споживача визначається фактично державним методом і розглядається як напрям діяльності держави. Ми вважаємо, що наявність публічного елементу слід розглядати не як певну державну діяльність чи втручання держави шляхом регулювання економіки, а лише в контексті вирівнювання фактичного становища учасників споживчих відносин, тобто йдеться тільки про обмеження диспозитивності у формуванні та реалізації цивільних правовідносин за участю фізичних осіб-споживачів задля захисту слабкої сторони договору та «вирівнювання» переговорних позицій учасників цих відносин. Однак регулювання саме публічно-правових відносин за участю споживачів цілком можливе за допомогою публічно-правового методу правового регулювання та регулювання економіки державою, здійснення державою своїх функцій без будь-якого комплексного змішування $з$ приватноправовими відносинами.

У цивілістичній науці висловлювалась думка про можливість включення до предмета торгового права (не підприємницького, а торгового) правовідносин за участю споживачів. Так, на думку Т.О. Батрової, питання захисту прав споживачів доцільно розглядати саме в рамках торгового права, оскільки саме з цього встановлюється більшість вимог до організації торгівлі [4]. Однак В.В. Богдан, не погоджуючись із цією позицією, зазначила, що захист прав споживачів не охоплюється тільки торговельною діяльністю, а в рамках його розуміння як діяльності між професійними учасниками товарного ринку, де послуги виконують лише допоміжну функцію, взагалі є неприйнятним. Можливо, в рамках підприємницького права такі мірку- вання можливі. Однак і в цьому разі виникають цілком обгрунтовані заперечення: інша спрямованість, інша точка зору на проблему захисту прав споживачів. По-перше, превалювання публічного регулювання в рамках підприємницької діяльності, по-друге, сприйняття самих норм будується за системою не «як захистити споживача», а як від нього захиститися. Універсальний механізм захисту, створений досі, можливо, втрачено не буде, але інтереси споживача втратять першочергове значення [5, с. 183-184]. Підтримуючи заперечення В.В. Богдан, відзначаємо, що споживчі відносини, хоча й набувають певної особливості, зокрема, шляхом базування на принципі пропорційності, проте не втрачають диспозитивних начал та принципу юридичної рівності учасників правовідносин. Більш того, саме принцип пропорційності є системоутворюючим у кваліфікації їх як особливого виду цивільних відносин, оскільки фактично відбувається поєднання диспозитивних правовідносин 3 імперативними з явним переважанням перших, тобто диспозитивність у формуванні та реалізації цивільних правовідносин за участю фізичних осіб-споживачів може обмежуватися задля захисту слабкої сторони договору та досягнення фактичної (об'єктивної) рівності учасників цих відносин.

С.Г. Буніна відзначає, що споживчі відносини належать до відносин майнових, входять до предмета правового регулювання цивільного права, проте мають специфіку. Специфіка цих відносин полягає перш за все в суб'єктному складі, адже споживче законодавство спрямоване на захист споживачів-громадян [6]. Водночас Г.Б. Яновицька цілком слушно вважає, що, будучи різновидом цивільно-правових відносин, правовідносини за участю споживачів є суспільними відносинами, регульованими нормами цивільного права, договірними умовами, правовими звичаями. Їм властивий вольовий характер. Саме споживач визначає власну модель поведінки щодо реалізації своїх прав [7, с. 96]. Таким чином, на переконання згаданих авторів, споживчі відносини регулюються нормами цивільного права, тому їх слід вважати цивільно-правовими.

Схоже міркування щодо віднесення споживчих відносин до предмета цивільного права свого часу було висловлено М.М. Агарковим [8, с. 136-137], який зазначив, що для задоволення своїх матеріальних і культурних потреб громадяни укладають договори 3 державними й кооперативними організаціями, а також один з одним. Договори з державними i кооперативними організаціями є договорами, у яких однією стороною є під- 
приємство, тобто планомірно діюча організація, яка керується певними правилами, які встановлюють порядок ії роботи. Ця обставина робить необхідним одноманітність щодо способу укладення та змісту операцій, що здійснюються з громадянами. У зв'язку 3 цим виникають питання щодо окремих галузей нашого господарства, що займаються обслуговуванням споживчих потреб громадян. Ці питання, оскільки вони стосуються цивільного права, головним чином зводяться до проблеми охорони прав споживачів [9, с. 137]. Фактично наведена позиція автора лаконічно обгрунтовує той факт, що приватноправові відносини за участю фізичних осіб слід кваліфікувати як особливий вид цивільних відносин з, акцентуємо, одноманітністю їх правового регулювання.

О.Ю. Єгоричева висловлює міркування, що споживчі правовідносини посідають центральне місце разом із відносинами власності в системі цивільних правовідносин. При цьому автор цілком слушно зазначає, що це обумовлює необхідність установлення ефективного правового механізму захисту прав споживачів [10]. Водночас у своєму дисертаційному дослідженні О.О. Райлян звертає увагу на те, що серед суспільних відносин, що підпадають під юрисдикцію споживчого права, переважне місце посідають майнові відносини. Ці відносини фактично $€$ цивільно-правовими, але водночас їх слід розцінювати як особливий вид цивільних майнових відносин, оскільки їм притаманні такі відмінні риси:

1) якщо цивільне право регулює дві основні групи майнових відносин, а саме відносини речового і відносини зобов'язального характеру, то споживче право регулює тільки другу групу майнових відносин;

2) цивільно-правові зобов'язальні відносини залежно від підстав їх виникнення можна поділити на три такі основні групи: виникають на основі різних договорів; деліктні, що виникають внаслідок заподіяння шкоди; ті, що виникають внаслідок безпідставного придбання або збереження майна, іменованого узагальнено як безпідставне збагачення; споживче право регулює переважно першу групу, а саме договірні відносини, третя група ним взагалі не охоплюється;

3) цивільно-правові майнові відносини виникають у процесі виробництва, розподілу, обміну та споживання засобів і продуктів виробництва; споживче право повністю функціонує лише на стадії споживання;

4) за суб'єктним складом відмінності полягають у тому, що споживче право регулює тільки ті відносини, учасниками яких, з одного боку, є індивідуальні підприємці та організації, а з іншого боку, громадяниспоживачі [1, с. 28].

Згадана автором відмінність, безумовно, $€$ цікавою, проте вважати ії еталонною для можливості виокремлення споживчих відносин у межах цивільних доволі неоднозначно. На нашу думку, споживче право регулюе публічно-правові та приватноправові відносини за участю фізичних осіб-споживачів, а цивільне право - лише приватноправові відносини за участю фізичних осіб-споживачів. Наочно наведену позицію продемонструвала О.М. Язвінська, на думку якої споживче право регулює відносини, що виникають у сферах публічного права, тобто процедура ліцензування діяльності у цій сфері, податкового регулювання, ціноутворення, регулювання стандартизації та сертифікації в цій сфері; приватного права, тобто ті відносини, які засновані на договорах купівлі-продажу, договору підряду, договорів 3 надання різноманітних послуг, а також відносини, які виникають у разі порушення прав споживачів [11]. Таким чином, слід провести чітку лінію між публічно-правовими та приватноправовими відносинами за участю фізичних осіб-споживачів, останні з яких ми називаємо споживчими відносинами і які належать до предмета цивільного права.

Крім того, загалом автор цілком справедливо зазначає, що споживчі відносини регулюються лише окремими положеннями цивільного права, тобто мають значно вужчий предмет правового регулювання. Однак факт регулювання цими окремими положеннями однорідної сукупності відносин сам по собі не свідчить про особливий вид відносин, що має певне відмінне правове регулювання від цивільних. Група однорідних відносин, що регулюються цивільним правом, може бути виділена, наприклад, в інститут, такий як зобов'язальне право, яке не має статусу особливого. Споживчі відносини як приватноправові поєднують і публічні, і приватні елементи правового регулювання, чим створюють спеціальне правове регулювання в межах цивільного права. Отже, хоча наведені автором відмінності, безумовно, відіграють певну роль у виокремленні споживчих відносин, недоцільно вважати їх системоутворюючими у формуванні цих відносин як окремого виду цивільних.

Окремо слід навести слушну позицію В.О. Анісімова, який, характеризуючи відмінності між споживчими відносинами і відносинами споживання, доволі вдало обгрунтовує приналежність перших до предмета цивільного права. Так, автор зазначає, що незважаючи на присутність елементів публічно-правового регулювання споживчих 
відносин, вони є частиною предмета цивільного права разом із відносинами споживання. Основними відмінностями споживчих відносин від відносин споживання є такі:

- споживчі відносини складаються в рамках майнового обігу і є майново-вартісними, а відносини споживання є майновими відносинами власності в іï статиці і реалізуються володінням, користуванням і розпорядженням матеріальними благами;

- відносини споживання розвиваються в рамках абсолютних правовідносин власності, а споживчі - в рамках відносних правовідносин (зобов'язання);

- споживчі відносини передують виникненню відносин споживання і складаються у сфері виробництва та обміну, але не безпосереднього споживання;

- споживання є метою для споживчих відносин і змістом для відносин споживання [12].

При цьому відзначаємо, що споживання як мета для споживчих відносин і зміст для відносин споживання дає змогу говорити про взаємопов'язаність цих відносин у контексті системного розуміння споживчих відносних як цивільно-правових, що відображають їх споживчий характер і не дають змогу говорити про споживчий характер публічно-правових відносин за участю споживача.

На переконання Г.А. Осетинської, сфера захисту прав споживача здебільшого перебуває саме у площині цивільного права оскільки правовідносини за участю споживачів виникають на підставі цивільно-правових договорів, а саме купівлі-продажу, підряду, договорів із надання послуг, які наділені захисною функцією, що являє собою механізм захисту порушених прав шляхом примусу до виконання обов'язку в натурі, відшкодування збитків, вжиття заходів оперативного впливу [13, с. 16]. При цьому автор зауважує, що до предмета цивільноправового регулювання входять такі майнові відносини за участю споживачів, у яких учасники не перебувають у стані владної підпорядкованості і виступають як незалежні, автономні суб'єкти. Такі відносини функціонують як зобов'язальні відносини, які виникають на підставі договору, а інколи делікту [13, с. 26]. Таким чином, підтримуючи позицію автора, можемо говорити про певний комплекс міжінституційних норм правового регулювання конкретних відносин у межах цивільного права, які, на наше переконання, слід називати саме споживчими.

Водночас слід зауважити, що споживчі відносини охоплюють не тільки майнові, але й особисті немайнові відносини. Так, відповідно до пункту 4 частини першої статті 4 Закону України «Про захист прав споживачів», споживачі під час укладення, зміни, виконання та припинення договорів щодо отримання (придбання, замовлення тощо) продукції, а також під час використання продукції, яка реалізується на території України, для задоволення своїх особистих потреб мають право на необхідну, доступну, достовірну та своєчасну інформацію державною мовою про продукцію, іiї кількість, якість, асортимент, їі виробника (виконавця, продавця) відповідно до Закону України «Про забезпечення функціонування української мови як державної», тобто під час укладення споживчого договору споживач має особисте немайнове право на отримання, зокрема, інформації про певний продукт, роботу чи послугу. Водночас наявність можливості відмовитися від укладення договору внаслідок отриманої інформації свідчить про існування переддоговірних прав споживача. Такі переддоговірні права слід вважати особистими немайновими, оскільки тільки після отримання необхідної, доступної, достовірної та своєчасної інформації державною мовою про продукцію споживач може прийняти зважене рішення про те, чи вступати в майнові відносини. При цьому відмова надати таку інформацію до моменту укладення договору буде вважатися порушенням його особистих немайнових прав, що підлягають відповідному захисту.

Споживчі відносини, на відміну від відносин за участю споживачів, охоплюються лише нормами цивільного права, включаючи ті, які мають публічний чи імперативний характер. При цьому саме розуміння споживчих відносин як виключно цивільноправових дає можливість говорити про відображення правового регулювання фактичної дійсності, тобто споживання благ, а не регулювання також публічно-правових відносин, тому виділення споживчих відносин в окремий самостійний чи комплексний вид суспільних відносин видається недоцільним.

\section{Висновки}

Отже, вищенаведене дає змогу зробити закономірний висновок, що споживчі відносини - це цивільно-правові відносини за участю фізичних осіб-споживачів. Як особливий вид цивільно-правових відносини споживчі відносини мають специфічний суб'єктний склад, особливість поєднання диспозитивного та імперативного правового регулювання, спеціальний об'єкт - блага, що задовольняють особисті потреби фізичних осіб.

Схематично місце споживчих відносин у системі цивільного права можна відобразити таким чином (рис. 1). 


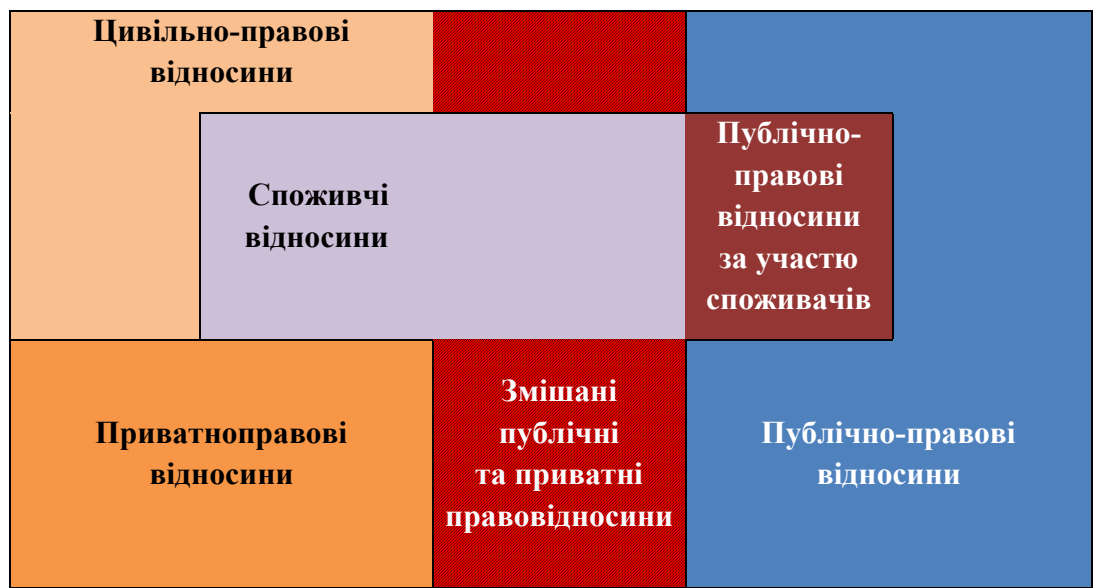

Рис. 1. Споживчі відносини у системі цивільного права

\section{Список використаних джерел:}

1. Райлян А.А. Теоретические основы потребительского права России: цивилистическое исследование : автореф. дис. ... докт. юрид. наук : спец. 12.00 .03 ; Казанский государственный университет им. В.И. Ульянова-Ленина. Казань, 2007. 45 c. URL: https://dlib.rsl.ru/ viewer/01003061280\#?page=1 (дата звернення: 14.07.2020)

2. Новицкий И.Б., Лунц Л.А. Общее учение об обязательстве. Москва : Государственное издательство юридической литературы, 1950. 416 с.

3. Банасевич I.I. Поняття та сутність правовідносин за участю споживачів. Юридичний бюлетень. 2018. № 7 (7). Ч. 1. С. 177-182. URL: http://www. lawbulletin.oduvs.od.ua/archive/2018/7_2018/ part 1/28.pdf (дата звернення: 21.01.2021).

4. Батрова Т.А. Проблемы правового регулирования торговых отношений. URL: https:// justicemaker.ru/view-article.php?id=9\&art=4422.

5. Богдан В.В. Гражданско-правовое регулирование защиты прав потребителей в современной России : проблемы теории и практики : дисс. ... докт. юрид. наук : спец. 12.00 .03 ; ЮгоЗападный государственный университет. Курск, 2015. 389 c. URL: https://www.swsu.ru/ds/dissswsu/Bogdan\%20disser.pdf (дата звернення: 14.06.2020)

6. Бунина С.Г. Потребительское право в системе современного российского права. Современное право. 2007. № 9. C. 2-5. URL: https:// www.sovremennoepravo.ru/m/articles/view/ Потребительское-право-в-системе-современногороссийского-права (дата звернення: 22.02.2021).
7. Яновицька Г.Б. Цивільно-правові засоби захисту прав споживачів в Україні : монографія. Львів : Растр-7, 2018. 400 с.

8. Агарков М.М. Обязательство по советскому гражданскому праву. Москва : Юридическое издательство НКЮ СССР, 1940. 192 с

9. Граве К.А. Договор розничной купли-продажи и охрана интересов граждан, ВИЮН, 1939 (рукопись) ; Зимелева М.В. Договор бытового подряда. Проблемы сочиалистического права. 1938. Кн. 4. Цит. по: Агарков М.М. Обязательство по советскому гражданскому праву. Москва : Юридическое издательство НКЮ СССР, 1940. 192 с.

10. Єгоричева О.Ю. Споживач як учасник споживчих правовідносин за законодавством України. Юридична Україна. 2012. № 7. С. 47-52. URL: http://nbuv.gov.ua/UJRN/urykr 2012 711 (дата звернення: 22.02.2021)

11. Язвінська О.М. Споживче право та споживче законодавство України. Економіка та управління на транспорті. 2015. Вип. 1. С. 130-135. URL: http://nbuv.gov.ua/UJRN/eut_2015_1_19 (дата звернення: 24.02.2021)

12. Анисимов В.А. «Потребительские отношения» и «Отношения потребления» в предмете гражданского права. Вестник ОмГУ. Серия: Право. 2017. № 2 (51). URL: https://cyberleninka.ru/ article/n/potrebitelskie-otnosheniya-i-otnosheniyapotrebleniya-v-predmete-grazhdanskogo-prava (дата звернення: 22.07.2020)

13. Осетинська Г.А. Цивільно-правовий захист прав споживачів за законодавством України : дис. ... канд. юрид. наук : спец. 12.00.03 ; НДІ приватного права і підприємництва Академії правових наук України. Київ, 2006. 220 арк.

\section{Roman Pozhodzhuk. The place of consumer relations in the system of civil law}

The scientific article is devoted to the analysis of consumer relations and the establishment of their place in the system of civil law. In particular, the author explores the essence of private law relations with the participation of individuals - consumers by analyzing the provisions of the current legislation of Ukraine and scientific positions on these relations. Besides, it is noted that the establishment of the place of consumer relations in the legal system of Ukraine is particularly relevant in the implementation of the Association 
Agreement between the European Union and its Member States, of the one part, and Ukraine, of the other part, in order to bring the legislation of Ukraine into the acquis communautaire. At the same time, in order to properly fulfill the relevant obligations of Ukraine, it is necessary to prepare an appropriate theoretical and legal framework.

Also, the article provides theoretical considerations on the differences between consumer and civil relations, argues that consumer relations cover both property and personal non-property relations, and argues that consumer relations are governed by civil law. The author substantiates the relationship between consumer relations (private law relations with the participation of individuals - consumers) and civil law. Additionally, within the framework of the study, consideration is expressed about the need to separate publiclaw and private-law relations with the participation of individuals - consumers, the latter of which are called "consumer relations" and which relate to the subject of civil law. Otherwise, the affinity between consumer and civil relations may be violated.

As a result, the author tries to determine the place of consumer relations in the system of civil law and concludes that consumer relations should be considered as civil relations with the participation of individuals - consumers. As a special type of civil law relations, consumer relations have a specific composition of participants, a feature of the combination of dispositive and imperative legal regulation, a special object - goods that meet the personal needs of individuals.

In addition, the author proposed a scheme, which represents a place of consumer relations in the civil law system.

Key words: consumer relations, civil law relations, consumer protection, private law relations, public law relations, consumer. 